\title{
Myxobolus buckei sp. n. (Myxozoa), a new pathogenic parasite from the spinal column of three cyprinid fishes from the United Kingdom
}

\author{
Matt Longshaw ${ }^{1}$, Paul Frear ${ }^{2}$ and Stephen W. Feist ${ }^{1}$ \\ ${ }^{1}$ CEFAS Weymouth Laboratory, Barrack Road, The Nothe, Weymouth, Dorset, DT4 8UB, UK; \\ ${ }^{2}$ Environment Agency, Coverdale House, Aviator Court, Amy Johnson Way, York, YO30 4GZ, UK
}

Key words: Myxozoa, Bivalvulida, Myxobolus, histopathology, spine, taxonomy, Leuciscus cephalus, Rutilus rutilus, Abramis brama

\begin{abstract}
Myxobolus buckei sp. n. is described from the spinal column of Leuciscus cephalus (L.), Rutilus rutilus (L.) and Abramis brama (L.) from freshwater rivers in the North of England. The plasmodia develop within the remnants of the embryonic notochord in the intervertebral spaces. The spores are large, measuring (in $\mu \mathrm{m}$ ) $14.0 \pm 0.7 \times 11.5 \pm 0.6$ (mean $\pm \mathrm{SD}$ ), smooth, round to ellipsoid in valvular view with several sutural edge markings. The polar capsules are pyriform and of equal size, measuring $7.5 \pm 0.5 \times 4.2 \pm 0.2$ (mean $\pm \mathrm{SD}$ ), with 11-12 turns of the polar filament arranged perpendicularly to the longitudinal axis of the polar capsule. The parasite has a large intercapsular appendix and large iodinophorous vacuole. The parasite can be differentiated from all known species of Myxobolus Bütschli, 1882 by a combination of the morphological characters defined. Infected fish show marked longitudinal compression of the body compared to uninfected individuals of the same year class, a feature which is pathognomonic for the disease. Histologically, host responses ranged from mild hypertrophy of the zygapophyseal process and expansion of the intervertebral membrane to complete hypertrophy and fusion of the vertebrae. Prominent notochord is present in the intervertebral spaces of infected fish and sporogony of the parasite leads to a vigorous focal inflammatory response involving proliferating fibroblast and osteogenic cells. The parasite causes a radial expansion of the centra and extensive dorsal and ventral outgrowths of the vertebrae leading to compression of the spinal cord and blood vessels running through the neural and haemal spines respectively. The parasite is considered highly pathogenic to juvenile cyprinids.
\end{abstract}

Skeletal abnormalities have been reported for a number of fish species under natural and experimental conditions. Most skeletal deformities occur during embryogenesis or early in the life of the fish. A number of factors can lead to these abnormalities including exposure to pesticides including organochlorides and organophosphates (Couch et al. 1979, Middaugh et al. 1990), heavy metals (Roberts 1989), inappropriate temperature or movement during critical phases of embryogenesis (Brown and Núñez 1998) and disease. Arguably, one of the most studied diseases causing skeletal deformities in fish is whirling disease caused by the myxozoan Myxobolus cerebralis Hofer, 1903. The parasite has a predilection for cartilage and infects fish prior to ossification. Subsequent destruction of the cartilage leads to skeletal deformities in salmonids (Hedrick et al. 1998). A number of other reports of myxozoans causing skeletal deformities have been published. They either cause deformities by direct association with and destruction of the skeletal elements as exemplified by $M$. cerebralis (see Table 1) or indirectly by infecting nervous tissues leading to spinal curvatures. The majority of spinal deformities associated with myxozoan infections appear to be related to infections in the nervous tissues. Lom et al. (1991) reported vertebral deformities in perch (Perca fluviatilis L.) which they attributed to Myxobolus sandrae Reuss, 1906 infections of the spinal cord leading to myopathy of the axial muscles and/or of asymmetrical changes in muscle tone as a result of damage to the nerves controlling muscle contraction. Lom et al. (1991) did not examine the brains of affected fish, although it has been suggested that myxozoan infection in brain tissues can lead to spinal deformities (Egusa 1985, Langdon 1987, Maeno et al. 1990, Rothwell and Langdon 1990). Myxozoan infections in brain tissues do not always produce spinal deformities but may produce abnormal or altered swimming behaviour and may thus be a function of the number, size and specific location of spores and/or plasmodia (Egusa 1985, Langdon 1990). Additionally, reductions in the swimming speeds of sockeye salmon infected with Myxobolus arcticus Pugachev et Khokhlov, 1979 in the brain have been reported (Moles and Heifetz 1998).

Roach, chub and bream are parasitized by at least 40 species of Myxobolus Bütschli, 1882. If subspecies of Leuciscus cephalus (L.) and Rutilus rutilus (L.) are included, the list becomes greater. The morphological measurements and site(s) of infection of Myxobolus spp. from these three hosts are listed in Table 2. Bucke and Andrews (1985) reported vertebral deformities in juvenile chub and suggested, without any measurements or detailed morphological studies apparently being done, that the parasite may be $M$. ellipsoides Thélohan, 1892. This tentative assignment to species has become 
accepted and numerous publications have referred to $M$. ellipsoides as a pathogenic species with a predilection for cartilage (Lom and Dyková 1992, Feist and Longshaw 2000). Following a survey of the parasites of juvenile cyprinids in Yorkshire and Humberside in the North of England, including the "type-locality" where deformed chub were first reported from, we are able to describe the parasite as a previously unidentified species, Myxobolus buckei sp. n. In addition, this paper describes the pathology associated with the parasite, examines its spatial and temporal distribution and considers the potential impact of the parasite on host populations.

\section{MATERIALS AND METHODS}

Young-of-the-year $(0+)$ cyprinid fish, aged between 3 and 5 months old were collected semi-quantitatively from a number of sites on the rivers Tyne, Wear, Tees, Swale, Ure, Derwent, Ouse, Nidd, Aire, Wharfe, Hull, Calder, Dearne, Don, Rother in Yorkshire and Humberside, the River Stour in Dorset and the river Avon in Wiltshire between 1993 and 1998. Fish were either caught using three sweeps with a $20 \mathrm{~m}$ $\times 2 \mathrm{~m}$ micromesh seine net set along the river margin at each site or caught by hand netting. All fish caught were killed by over-anaesthetizing in MS222 then fixed in $10 \%$ neutral buffered formalin (NBF).

On return to the laboratory, fish were identified to species, fork length was taken and the fish stored in NBF by site and species. For histological studies a sub-sample of fry of each species from each site for each year were taken. A maximum of 30 fish of each species per site were examined. Tissues were softened in $10 \%$ formic acid for up to four days, transferred to $70 \%$ Industrial Methylated Sprits (IMS) until being processed to wax blocks on an automatic vacuum infiltration tissue processor. Sections were cut at 3-5 $\mu \mathrm{m}$ and stained routinely with Haematoxylin \& Eosin (H\&E) or Giemsa stain.

Fresh spores were isolated from samples of fish collected in Yorkshire during June and September 2002 and measurements, photographs and drawings were taken from these samples. Representative images of spores and pathologies were captured, and spores were measured using a Nikon Eclipse E800 microscope with LUCIA ${ }^{\mathrm{TM}}$ screen measurement system. Myxozoans were described and measured according to the criteria of Lom and Arthur (1989). Representative samples of spores were air-dried on glass slides, acetic-methanol fixed, and stained with May-Grünwald-Giemsa. Stained spores and sectioned material from each fish host were deposited in the Registry of Aquatic Pathology (RAP), CEFAS Weymouth and stained spores from Leuciscus cephalus and Rutilus rutilus were deposited in the collection of the Institute of Parasitology, Academy of Sciences of the Czech Republic, České Budějovice. Measurements and drawings of $M$. buckei spores were compared to published descriptions of Myxobolus spp. reported to occur in cartilage (Table 1) as well as those reported from roach, chub and bream (Table 2). For authorities for each species please refer to Landsberg and Lom (1991).

For scanning electron microscopy (SEM) studies of spores, two methods were used: (1) Spores isolated from dissected fish were fixed in $2.5 \%$ glutaraldehyde in sodium cacodylate buffer, $\mathrm{pH}$ 7.4, for a minimum of 24 hours. Spores were then filtered through a $0.1 \mu \mathrm{m}$ ceramic filter; post fixed in $1 \%$ osmium tetroxide in sodium cacodylate buffer, $\mathrm{pH} 7.4$, for 1 hour and dehydrated through an acetone series. Filters were critical point dried and sputter coated with $4 \mathrm{~nm}$ of gold and examined in a JEOL 5200 SEM at $25 \mathrm{kV}$. (2) Histological blocks containing infected fish were dewaxed and post-fixed in xylene containing liquid osmium tetroxide $(1 \% \mathrm{w} / \mathrm{v})$. Samples were held at $37^{\circ} \mathrm{C}$ for up to 60 minutes until the wax had dissolved then rinsed in several changes of xylene at room temperature. Samples were critical point dried, sputter coated and examined as above. For examination of vertebral elements by SEM, spinal columns of freshly killed fish were removed intact from fish showing external symptoms of infection and placed in distilled water. The soft tissues were allowed to disintegrate for approximately 1 month at $15^{\circ} \mathrm{C}$, after which individual vertebrae were rinsed in fresh distilled water to remove remnants of soft tissues, mounted and coated with 4 $\mathrm{nm}$ of gold and examined as above.

\section{RESULTS}

A total of 4,866 fish were examined histologically, comprising 1,001 roach [Rutilus rutilus (L.)], 1,258 chub [Leuciscus cephalus (L.)], 501 dace [Leuciscus leuciscus (L.)], 1,798 minnow [Phoxinus phoxinus (L.)], 28 bleak [Alburnus alburnus (L.)], 52 bream [Abramis brama (L.)] and 228 gudgeon [Gobio gobio (L.)]. In addition, 30 freshly killed fish were examined to assist in the identification and descriptions of the parasite. Infected fish were only found at 9 sites on 8 rivers, out of 30 sites from 17 rivers examined (see Table 3). Roach, chub and bream were infected each exhibiting similar (see below) pathological responses. Prevalence in rivers positive for $M$. buckei ranged between 0 and $68.42 \%$ (see Table 3). In addition, one minnow from Boston Spa collected in 1993 and one minnow each from Kirk Hammerton collected in 1997 and 1998 harboured a Myxobolus infection in the spinal column. One dace each collected in 1996 and 1998 from Low Moor, River Tees and three dace collected from upstream of Linton Weir in 1998 also had a Myxobolus infection in the spinal column. In dace and minnow, this Myxobolus sp. may be conspecific with M. buckei; however the host response to the parasite was minimal. Prevalence of infection in infected rivers was between $3.33 \%$ and $68.42 \%$. Infected bream were only found at Boston Spa in 1996 and at Hempholme in 1997. Infected chub were found at Bellflask in 1998, Boroughbridge in 1993, Boston Spa in 1993, 1994, 1995, 1996 and 1997, Carleton Bridge in 1993, Croft in 1998, Kirk Hammerton in 1998, upstream of Linton Weir in 1998 and Thornton Bridge in 1996. Infected roach were only found at Hempholme in 1994, 1995, 1996 and 1997. All other species of fish examined were negative by histological assessment. 


\section{Myxobolus buckei sp. n.}

Figs. 1-3

Vegetative stages. Small, white, round to ellipsoid plasmodia measuring $0.3-0.6 \mathrm{~mm}$ present in the intervertebral spaces. In latter stages of infection, plasmodia trapped within ossified elements of spine.

Spores. Spores typical of the genus Myxobolus. Mature spores smooth, round to ellipsoid with several sutural edge markings (normally 5-7), slightly variable in shape (Figs. 1-3). Polar capsules pyriform, apical of equal size. Polar filament with 11-12 coils, perpendicular to the longitudinal axis of the polar capsule. Large intercapsular appendix. Sporoplasm binucleate, filling entire extracapsular spore cavity. Large iodinophorous vacuole. Spore dimensions $(\mu \mathrm{m})$ based on 30 fresh specimens from Leuciscus cephalus, as range with means \pm SD in parentheses: 12.6-15.4 (14.0 \pm 0.7$) \times$ 10.2-12.4 (11.5 \pm 0.6$)$. Polar capsules of equal size extend beyond the mid-length of the spore and measure $6.0-8.6(7.5 \pm 0.5) \times 3.3-4.6(4.2 \pm 0.3)$.

T y p e h o s t: Leuciscus cephalus (L.) (Pisces: Cyprinidae).

$\mathrm{O}$ t h e r h o s t s : Abramis brama (L.), Rutilus rutilus (L.). Possibly Phoxinus phoxinus (L.) and Leuciscus leuciscus (L.).

T y p e 1 o c a 1 i t y : Boston Spa, River Wharfe, UK (NGR SE433457).

O t h e r l o c a 1 i t i e s : Bellflask and Boroughbridge, River Ure; Carleton Bridge, River Aire; Croft, River Tees; Hempholme, River Hull; Kirk Hammerton, River Nidd; upstream of Linton Weir, River Ouse; Thornton Bridge, River Swale.

$\mathrm{S}$ i t e of i n f e c t i o $\mathrm{n}$ : Plasmodia initially in the intervertebral spaces of the spinal column, replacing the notochord. Spores and plasmodia eventually found in cartilaginous and ossified elements of the spinal column.

Prevale n c e : Up to $68 \%$.

$\mathrm{T}$ y p e m a t e r i a 1: Syntype slides of histological sections of whole fish stained with $\mathrm{H} \& \mathrm{E}$ and with Giemsa stain have been deposited in the Registry of Aquatic Pathology, CEFAS Weymouth [Abramis brama (RAP Accession No. 807); Leuciscus cephalus (RAP Accession No. 808); Rutilus rutilus (RAP Accession No. 809)]. May-GrünwaldGiemsa stained smears of isolated spores from roach and chub have also been deposited in the RAP with the same accession numbers and in the collection of the Institute of Parasitology, Academy of Sciences of the Czech Republic, České Budějovice, Nos. DPF-007 and DPF-008.

E t y m o log y: This parasite is named for Mr. David Bucke formerly of the CEFAS Weymouth Laboratory who first reported the infection in juvenile Leuciscus cephalus (Bucke and Andrews 1985).

\section{Taxonomic affinities}

The original report of $M$. buckei in chub was tentatively referred to as M. ellipsoides. However, M. ellipsoides is elliptical, with either a small or non-existent intercapsular appendix and is smaller than M. buckei both in length and width and has smaller polar capsules.
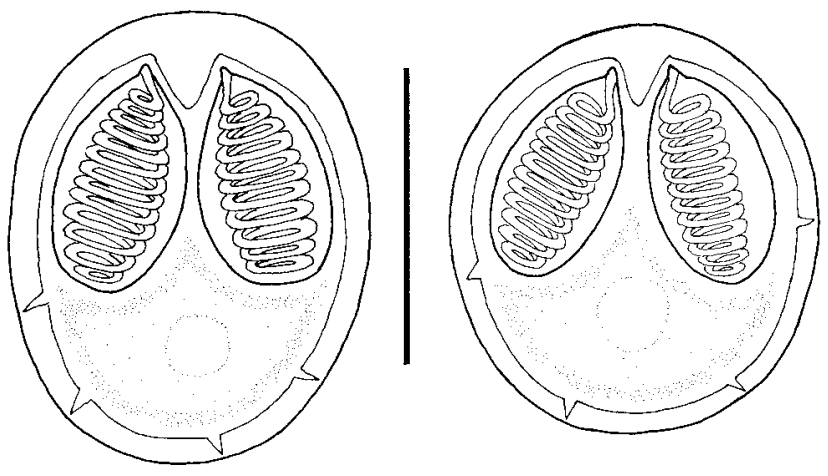

Fig. 1. Myxobolus buckei sp. n., frontal view of mature spore. Scale bar $=10 \mu \mathrm{m}$.

Most of the 40 Myxobolus spp. reported from roach, chub and bream can be discriminated from M. buckei as they do not resemble it morphologically in valvular view with the exception of $M$. bramae, M. branchialis, M. dogeli, M. muelleri, M. muelleriformis, M. multiplicatus, M. nemachili, M. pfeifferi, M. schulmani and M. squamaphilus. M. bramae occurs on the gills and overall is smaller than $M$. buckei in all dimensions. The polar capsules of $M$. branchialis are widely spaced and in overall dimensions, the spores of $M$. branchialis are smaller. Spores of $M$. dogeli narrow slightly at the anterior end, have a much wider sutural line and do not possess sutural edge markings. $M$. muelleri morphology is highly variable. However, it can be discriminated from $M$. buckei by a number of features. The intercapsular appendix is smaller than in $M$. buckei, has more sutural edge markings and only 5 to 8 filament turns in the polar capsule. In addition, the polar capsules are smaller than in $M$. buckei and do not extend beyond the midline of the spore. M. muelleriformis is much rounder than $M$. buckei, is smaller and does not possess sutural edge markings. M. multiplicatus is more ellipsoid and has 12-14 sutural edge markings, the polar capsules do not extend beyond the midline of the spore, and are shorter than those in M. buckei. M. nemachili possesses a greater number of sutural edge markings, smaller polar capsules and a smaller intercapsular appendix. The polar capsules of M. pfeifferi do not extend beyond the midline of the spore, and the intercapsular appendix is small. Whilst the length of M. pfeifferi spores falls within the range of $M$. buckei the width is smaller. M. schulmani is much larger than M. buckei in all dimensions and has a large intercapsular appendix. M. squamaphilus spores are larger than $M$. buckei in both length and width and are more ellipsoid in shape and there are only 7 turns to the polar filament in $M$. squamaphilus compared with 11-12 in M. buckei.

Of the Myxobolus spp. having a predilection for cartilaginous tissues of freshwater fishes, M. buckei can be differentiated from most, as it does not resemble them in valvular view. The remaining six can be 
discriminated as follows. M. cerebralis is smaller than $M$. buckei, possesses no intercapsular appendix, no sutural edge markings and only has 5-6 turns to the polar filament. $M$. filamentosus spores are narrower than M. buckei with smaller polar capsules and 5-6 turns of the polar filament. M. hoffmani is smaller; possesses more sutural edge markings with fewer filament turns. M. hyborhynchi is also smaller and the polar capsules extend well beyond the midline of the spore. Spores of $M$. indirae are oval to spherical in valvular view with a slightly pointed anterior end and possess polar capsules that are smaller, do not extend beyond the midline of the spore and possess 8-10 turns of the polar filament. $M$. petruschewskii is completely spherical in valvular view, and is smaller than M. buckei both in its overall size and in the size of the polar capsules.

In summary, $M$. buckei does not conform to any of the descriptions of Myxobolus spp. previously reported from cyprinids in the UK or Europe and can be differentiated from all known species of Myxobolus by the presence of a large intercapsular appendix, its somewhat large size and overall dimensions, polar capsules extending below the mid-line, 11-12 coils in the polar capsule and its tissue tropism.

\section{Development and pathogenicity}

Externally infected fish show marked longitudinal compression of the body compared to uninfected individuals of the same year class (Fig. 4). This compression of the fish is pathognomonic for the disease. Lordosis or scoliosis not seen. The normal architecture (Fig. 5) of the vertebrae is disrupted in the presence of the parasite plasmodia and spores (Figs. 6, 7). A variety of vertebral lesions were exhibited in fish parasitized by M. buckei, ranging from mild hypertrophy of the zygapophyseal process and expansion of the intervertebral membrane to complete hypertrophy and fusion of the vertebrae (Figs. 8, 9). The extent of pathological change appears to be dependent on the degree of ossification of the host at the time of exposure and presumably the parasite invades the host prior to ossification. The parasite has a predilection for cartilaginous tissue and the remnants of the embryonic notochord and plasmodia are found in the intervertebral spaces (Fig. 10) of both the caudal and precaudal vertebrae. The longitudinal compression noted externally is apparent in histological sec- tions (Fig. 9) with a concomitant marked hypertrophy of the vertebral walls (Figs. 11-13). In heavy infections, all elements of the vertebrae are affected including hypertrophy of the zygapophyseal processes to accommodate the developing plasmodia. Hypertrophy of the vertebral centra wall and fusion of adjoining centra is common. In intervertebral spaces infected by the parasite, prominent notochord is present. There is a vigorous focal inflammatory response involving proliferating fibroblast (Fig. 11) and osteogenic cells to the presence of the parasite. The parasite causes a radial expansion of the centra and intervertebral membrane (Fig. 12) and extensive dorsal and ventral outgrowths of the vertebrae (Fig. 10) leading to compression of the spinal cord and blood vessels running through the neural and haemal spines respectively (Figs. 12, 13). Sporogony is asynchronous with different plasmodia developing at different rates (Fig. 14). Loose parasites become trapped in a number of spaces associated with the vertebrae (Figs. $15,16)$ and within the ossifying cartilage (Fig. 17) although no destruction of parasite stages is apparent.

\section{DISCUSSION}

Bucke and Andrews (1985) reported the presence of a Myxobolus sp. associated with wild Leuciscus cephal$u s$, which they tentatively assigned to $M$. ellipsoides. We have been able to collect samples of fish from the same site that Bucke and Andrews (1985) used to describe the pathology associated with that Myxobolus sp. In addition, a re-examination of the original samples collected by Bucke and Andrews (1985) has confirmed that the pathology described in the original report conforms to that contained herein. Consequently the parasite infection described by Bucke and Andrews (1985) is due to M. buckei and not M. ellipsoides. We propose that $M$. ellipsoides is not a pathogenic species, at least not as previously reported in chub with spinal deformities. The report by Bucke and Andrews (1985) was based on the histological assessment of three fish from one site on a Yorkshire river. We have been able to extend the work to include a larger number of rivers and collect temporal data on parasite prevalence. In many of the sites sampled, $M$. buckei occurs sporadically, appearing in some years and not in others. At

Fig. 2. Myxobolus buckei sp. n. viewed under differential interference contrast microscopy. Fig. 3. Scanning electron microscopy images of $M$. buckei spores. a-c - isolated spores, note presence of sutural edge markings; $\mathrm{d}$ - view of spores in-situ in material previously prepared for histological examination. Presence of sutural edge denoted by arrow. Fig. 4. Normal (a) and infected (b) young-of-the-year Leuciscus cephalus. Note very apparent longitudinal compression of infected fish compared with uninfected fish from the same year class. Fig. 5. Histological section through an uninfected chub vertebrae, where sc - spinal cord, d digenean, ns - neural spine, $\mathrm{n}$ - notochord, ivm - intervertebral membrane. Giemsa stain. Fig. 6. Scanning electron microscopy image showing anterior face of vertebrae isolated from chub parasitized by $M$. buckei. Note the distended and distorted anterior face and zygapophyseal elements. Fig. 7. Scanning electron microscopy image of the posterior face of infected vertebrae. Fig. 8. Histological section through vertebrae of chub showing mild symptoms of infection with $M$. buckei. Giemsa stain. Fig. 9. Severe compression and fusion of vertebral elements of bream infected with $M$. buckei. Note inflammatory response in periphery of neural and haemal spines. H\&E. Scale bars: Fig. $2=10 \mu \mathrm{m}$; Fig. $3=5 \mu \mathrm{m}$; Fig. $4=10$ mm; Figs. 5, 8, $9=50 \mu \mathrm{m}$; Figs. $6,7=$ $500 \mu \mathrm{m}$. 
Longshaw et al.: Myxobolus buckei sp. n.

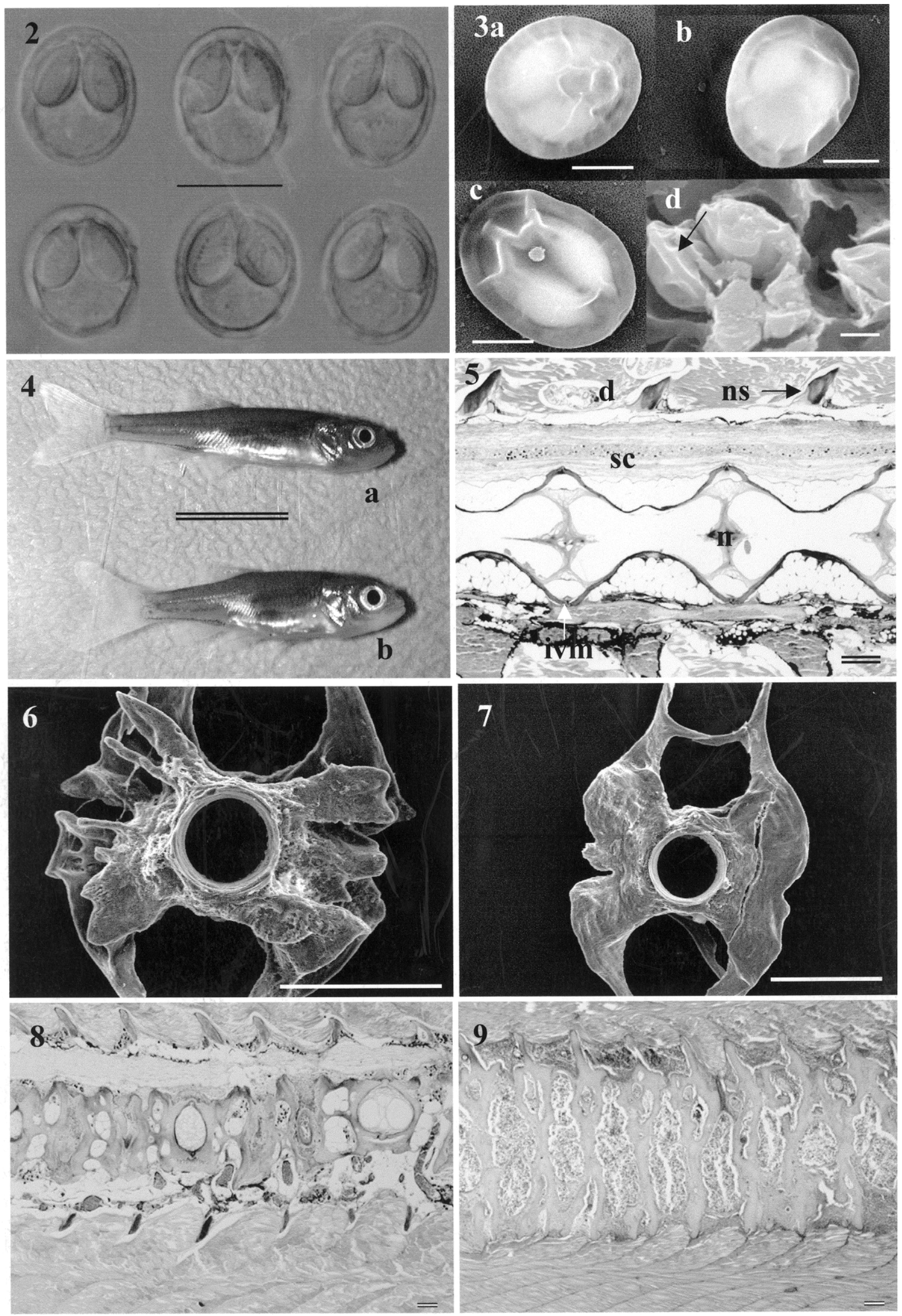


Boston Spa, 0+ chub are consistently infected with prevalences ranging from $20 \%$ to $68 \%$. In contrast, chub from Boroughbridge were infected at a prevalence of around $21 \%$ in 1993 , and the parasite has not been recorded from this site since. Interestingly, infected roach were only recorded at Hempholme, despite being caught at other sites where chub were infected. The factors which specifically predispose roach to infections by $M$. buckei at that site and for the variations in host susceptibility and in spatial and temporal differences are unknown but may be related to a number of multifactorial biotic and abiotic factors. It is known that at each site and in different years other diseases are present or absent (Longshaw and Feist, unpublished data), including other myxozoans, digeneans such as Bucephalus polymorphus and coccidian infections which may interact synergistically with $M$. buckei to exacerbate the host susceptibility.

Landsberg and Lom (1991) listed 444 species of Myxobolus that have been described from fish and amphibians. That number has risen over the past decade due to further descriptions (e.g. Chen and Ma 1998) and confirmation of the taxonomic status of some species (Molnár et al. 2002). A large number of Myxobolus spp. have been described from cyprinids around the world, and within the genera Rutilus, Leuciscus and Abramis at least 40 species have been reported. There was some controversy regarding the use of tissue tropism as a valid taxonomic criterion for myxozoans until the work of Andree et al. (1999) that demonstrated, using rDNA sequence information, that tissue specificity in Myxobolus spp. could be used as a diagnostic criteria. The extreme tissue specificity exhibited by $M$. buckei is further evidence of this phenomenon. It is recognised that some myxozoan infections can show low host specificity, especially amongst the cyprinid-infecting myxozoans, whilst maintaining high tissue specificity (Hedrick et al. 1993, 1998, Molnár et al. 2002). Since M. buckei appears to be a parasite of at least four genera and five cyprinid species it is not unusual in this respect.

The presence of the parasite in $P$. phoxinus and $L$. leuciscus is unusual in that the tissue responses to the parasite are markedly different to the responses in the other three hosts. In dace and minnow there is only a slight expansion of the intervertebral membrane. The reason for this is unclear but may be due to minnow and dace being accidental hosts or related to the biology of the fish. It is known that dace spawn earlier than roach, bream and chub in UK waters. By spawning earlier, dace are able to ossify sooner than other hosts in the river system and will presumably move out of the river margins once they reach a suitable size. If the ossification occurs prior to the release of presumptive actinospore stages, dace may be able to mitigate the effect of the parasite.

The severity of the disease caused by M. buckei in roach, chub and bream appears to be related to the degree of osteological development. Data on the ossification of cartilage in fish is lacking, though Economou et al. (1991) suggested that ossification of the spinal column of L. cephalus occurred in fish over $8 \mathrm{~mm}$ in length. Therefore it would be expected that the infection of fish by the parasite should occur when fish are smaller than $8 \mathrm{~mm}$. The presence of spore forms of the parasite in fish that are approximately 3-5 months old would support the idea that sporogony occurs rapidly in these hosts and that infections occur very early in the development of the fish. Markiw (1992) demonstrated that $M$. cerebralis developed in two-month-old rainbow trout that were ossifying when exposed to actinospore stages of the parasite. However, many did not display clinical signs of whirling disease. Whilst Markiw (1992) was able to infect older, ossified fish with actinospore stages of $M$. cerebralis, all of these fish were asymptomatic for clinical signs of whirling disease. Whether chub, roach and bream can be infected but not display the characteristic spinal compression and fusion after ossification occurs remains unknown. In M. cerebralis infections, fish show signs of the characteristic "whirling" motion and in some cases skeletal deformities (MacConnell and Vincent 2002). Rose et al. (2000) demonstrated that the whirling behaviour is a consequence of pressure on the spinal cord and lower brain stem. Whilst cyprinids infected with $M$. buckei do not exhibit signs of whirling suggestive of an effect on the nervous control mechanisms, the obvious compression of the spinal cord strongly implies that the developing parasite is detrimental to the nervous system. Infected fish show erratic swimming patterns characterised by a short, jerky lateral motion. Burst swimming is compromised with few infected fish able to sustain long periods of burst activity or typical escape behaviour (M. Longshaw, unpublished observations). The combination of spinal cord compression and fusion of the vertebrae

Fig. 10. Plasmodia of Myxobolus buckei (arrowed) in the intervertebral spaces. Both precaudal and caudal vertebrae are infected as denoted by the position of the hind kidney (k). Fig. 11. Inflammatory response $(*)$ surrounding centra of infected vertebrae. Parasite plasmodia (p) are apparent in between successive vertebrae. H\&E. Fig. 12. Expansion of the intervertebral membrane (ivm) by parasite plasmodia (p) leading to compression of the spinal cord $(*)$. Note the difference in morphology of the anterior (asc) and posterior (psc) spinal cord. H\&E. Fig. 13. Limited expansion of intervertebral membrane causing compression of the spinal cord. Fig. 14. Develop-ment of spores within plasmodia (p) situated between successive vertebrae. Note the difference in development of spores between the two adjacent plasmodia. H\&E. Fig. 15. Presence of $M$. buckei spores in the spaces between the spinal cord, vertebral elements and nerve bundles. The parasite is absent from the nervous tissue. Giemsa stain. Fig. 16. $M$. buckei spores (arrowed) trapped in a fibroblast matrix. Giemsa stain. Fig. 17. M. buckei spores (arrowed) trapped within ossified cartilage of the vertebrae. Giemsa stain. Scale bars: Fig. $10=1 \mathrm{~mm}$; Figs. $11-17=50 \mu \mathrm{m}$. 


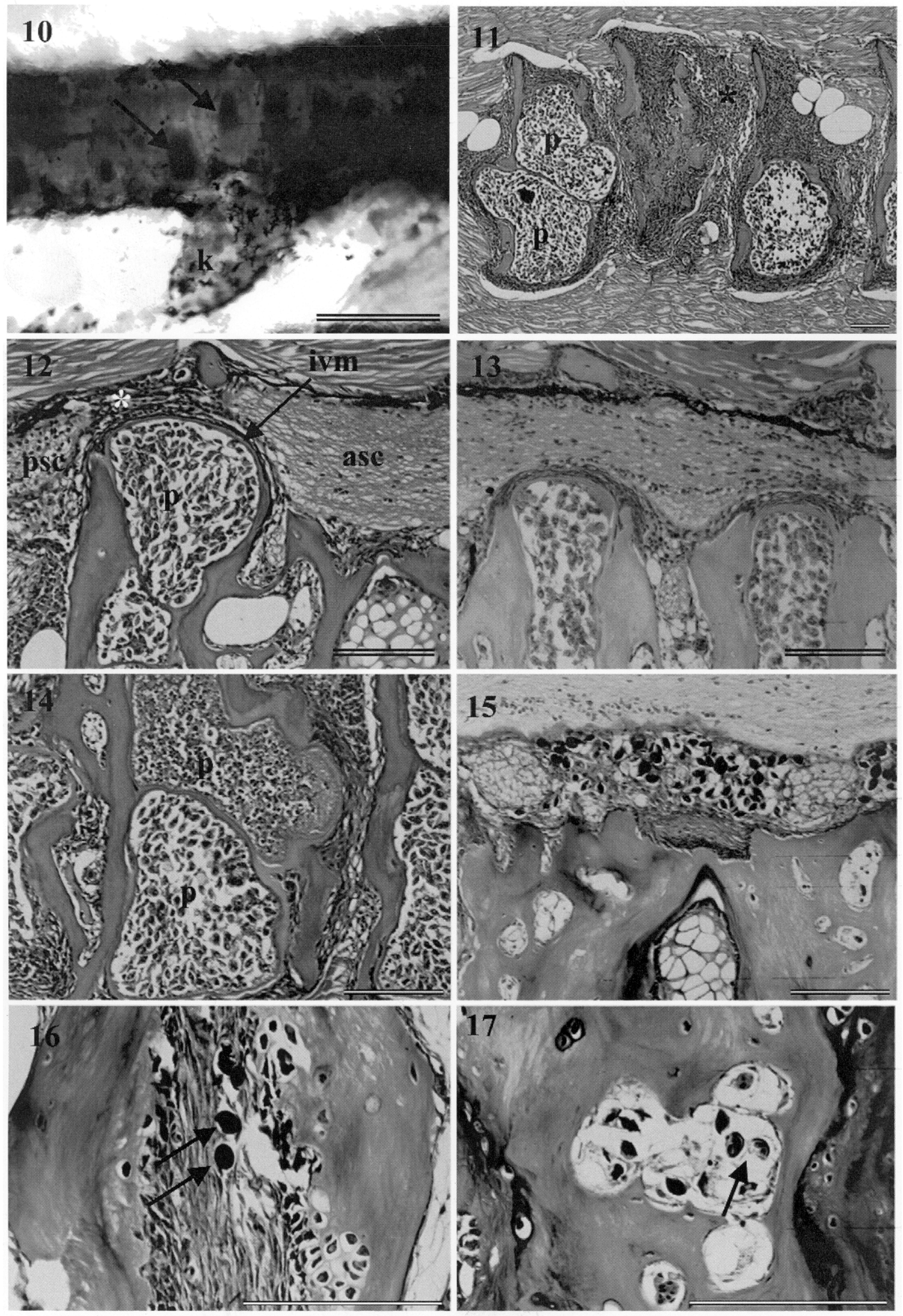


Table 1. Hosts and spore dimensions of Myxobolus spp. reported from cartilage in freshwater fishes. All measurements in $\mu \mathrm{m}$. Where $+=$ present, $-=$ absent, $+/-=$ sometimes, $\mathrm{ND}=$ no data.

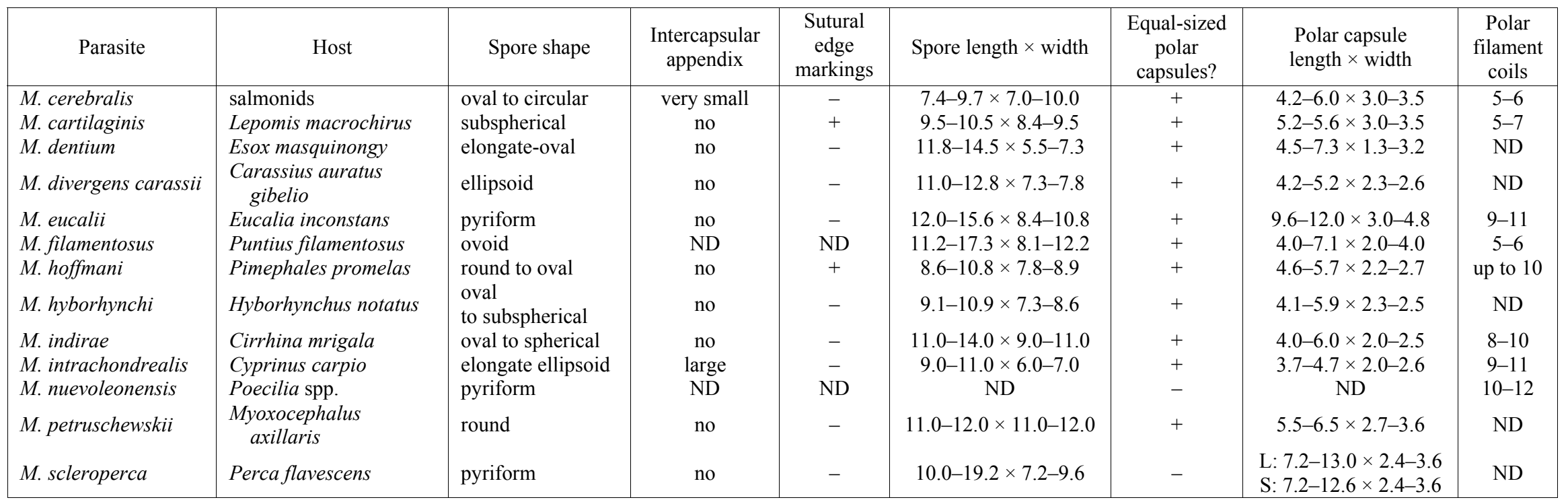

Table 2. Comparison of Myxobolus buckei sp. n. with all Myxobolus spp. reported from Abramis brama, Leuciscus cephalus and Rutilus rutilus. All measurements in $\mu$ m.

Where $\mathrm{Ab}=$ Abramis brama, $\mathrm{Lc}=$ Leuciscus cephalus, $\mathrm{Rr}=$ Rutilus rutilus, $+=$ present, $-=$ absent, $+/-=$ sometimes, $\mathrm{ND}=$ no data.

\begin{tabular}{|c|c|c|c|c|c|c|c|c|c|c|c|}
\hline \multirow{2}{*}{ Parasite } & \multicolumn{3}{|c|}{$\begin{array}{l}\text { Presence } \\
\text { in hosts }\end{array}$} & \multirow{2}{*}{ Site of infection } & \multirow{2}{*}{ Spore shape } & \multirow{2}{*}{$\begin{array}{l}\text { Intercapsular } \\
\text { appendix }\end{array}$} & \multirow{2}{*}{$\begin{array}{l}\text { Sutural } \\
\text { edge } \\
\text { markings }\end{array}$} & \multirow{2}{*}{$\begin{array}{c}\text { Spore } \\
\text { length } \times \text { width }\end{array}$} & \multirow{2}{*}{$\begin{array}{l}\text { Equal- } \\
\text { sized } \\
\text { polar } \\
\text { capsules }\end{array}$} & \multirow{2}{*}{$\begin{array}{l}\text { Polar capsule } \\
\text { length } \times \text { width }\end{array}$} & \multirow{2}{*}{$\begin{array}{l}\text { Polar } \\
\text { filament } \\
\text { coils }\end{array}$} \\
\hline & $\mathrm{Ab}$ & $\mathrm{Lc}$ & $\mathrm{Rr}$ & & & & & & & & \\
\hline M. buckei sp. n. & + & + & + & spinal column & round to ellipsoid & large & + & $12.6-15.4 \times 10.2-12.4$ & + & $6.0-8.6 \times 3.3-4.6$ & 11-12 \\
\hline M. albovae & + & + & - & gills & oval & large & - & $10.5-13.0 \times 8.0-9.8$ & + & $4.8-5.5 \times 2.7-3.3$ & ND \\
\hline M. bramae & + & + & + & gills and others & widely oval & large & $+/-$ & $9.0-15.0 \times 8.0-12.0$ & + & $4.0-7.2 \times 2.5-3.0$ & $6-7$ \\
\hline M. branchialis & - & - & + & gills & close to round & small & - & $6.8-8.5 \times 5.8-7.6$ & + & $2.5-4.1 \times 1.6-2.0$ & ND \\
\hline M. carassii & + & - & + & body cavity & ovate, narrow anteriorly & small & - & $13.0-17.0 \times 8.0-11.0$ & + & $5.6-8.5 \times 3.5-4.0$ & ND \\
\hline M. chernovae & - & - & + & gills & pyriform & no & - & $8.5-10.0 \times 6.5-7.0 ?$ & + & $5.5 \times 3.0-4.0$ & ND \\
\hline M. circulus & + & - & - & gills and others & close to round & no & - & $8.5-12.0 \times 7.5-12.0$ & + & $3.5-6.0 \times 3.4$ & $5 ?$ \\
\hline M. cycloides & + & + & + & gills & elongate ellipsoid & small & + & $12.6-15.0 \times 9.0-11.0$ & + & $5.4-7.2 \times 3.0-4.5$ & $5-6$ \\
\hline M. dispar & + & + & + & gills & oval, narrow anterior end & large & $+/-$ & $9.0-14.0 \times 7.5-10.0$ & - & $\begin{array}{l}\mathrm{L}: 5.0-8.0 \times 3.0-4.5 \\
\text { S: } 2.5-4.5 \times 2.0-2.7\end{array}$ & $\begin{array}{l}\text { L: } 6-8 \\
\text { S: } 3-6\end{array}$ \\
\hline M. diversicapsularis & - & - & + & gills & widely oval to round & small & - & $8.5-13.0 \times 8.5-12.5$ & - & $\begin{array}{l}\text { L: } 3.8-5.5 \times 2.2-3.7 \\
\text { S: } 2.2-3.3 \times 1.1-2.5\end{array}$ & $\begin{array}{l}\text { L: } 7-8 \\
\text { S: } 4\end{array}$ \\
\hline
\end{tabular}


Table 2. Continued.

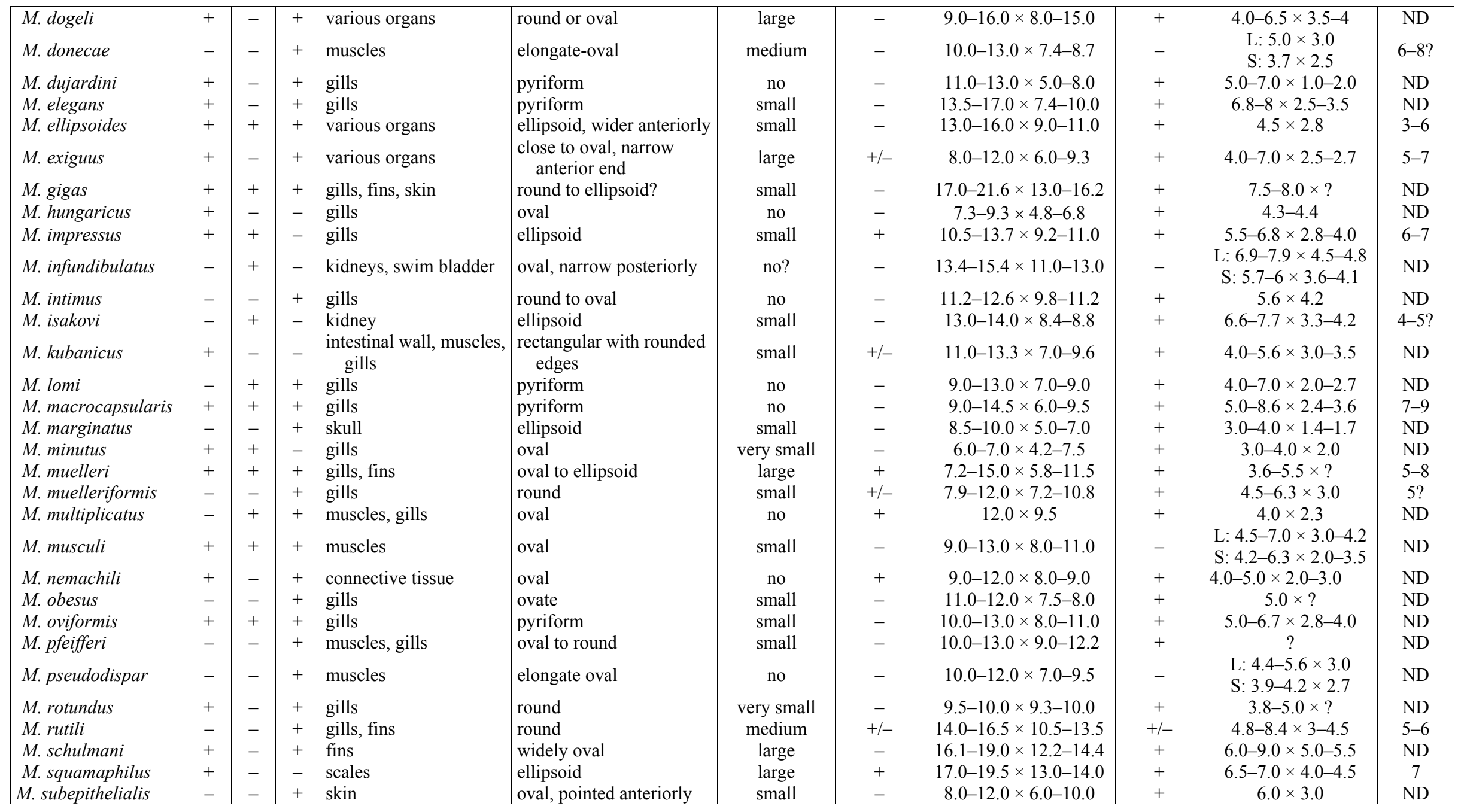


Table 3. List of sites, grid references (NGR), numbers of fish examined (n) and prevalence (\%) of M. buckei in Abramis brama, Leuciscus cephalus and Rutilus rutilus.

\begin{tabular}{|c|c|c|c|c|c|c|c|c|c|c|c|c|c|c|}
\hline \multirow{2}{*}{ Site } & \multirow{2}{*}{ NGR } & \multirow{2}{*}{ Species } & \multicolumn{2}{|c|}{1993} & \multicolumn{2}{|c|}{1994} & \multicolumn{2}{|c|}{1995} & \multicolumn{2}{|c|}{1996} & \multicolumn{2}{|c|}{1997} & \multicolumn{2}{|c|}{1998} \\
\hline & & & $\mathrm{n}$ & $\%$ & $\mathrm{n}$ & $\%$ & $\mathrm{n}$ & $\%$ & $\mathrm{n}$ & $\%$ & $\mathrm{n}$ & $\%$ & $\mathrm{n}$ & $\%$ \\
\hline Ure, Bellflask & SE295775 & $\begin{array}{l}\text { A. brama } \\
\text { L. cephalus } \\
\text { R. rutilus }\end{array}$ & $\begin{array}{l}- \\
- \\
-\end{array}$ & $\begin{array}{l}- \\
- \\
-\end{array}$ & $\begin{array}{l}15 \\
- \\
-\end{array}$ & $\begin{array}{l}0 \\
- \\
-\end{array}$ & $\begin{array}{l}- \\
- \\
-\end{array}$ & $\begin{array}{l}- \\
- \\
-\end{array}$ & $\begin{array}{l}- \\
- \\
-\end{array}$ & $\begin{array}{l}- \\
- \\
-\end{array}$ & $\begin{array}{l}- \\
- \\
-\end{array}$ & $\begin{array}{l}- \\
- \\
-\end{array}$ & $\begin{array}{l}- \\
30 \\
-\end{array}$ & $\begin{array}{c}- \\
16.67 \\
-\end{array}$ \\
\hline Ure, Boroughbridge & SE397670 & $\begin{array}{l}\text { A. brama } \\
\text { L. cephalus } \\
\text { R. rutilus }\end{array}$ & $\begin{array}{l}- \\
14 \\
10\end{array}$ & $\begin{array}{c}- \\
21.43 \\
0\end{array}$ & $\begin{array}{l}- \\
23 \\
-\end{array}$ & $\begin{array}{l}- \\
0 \\
-\end{array}$ & $\begin{array}{l}- \\
9 \\
8\end{array}$ & $\begin{array}{l}- \\
0 \\
0\end{array}$ & $\begin{array}{c}7 \\
20 \\
20\end{array}$ & $\begin{array}{l}0 \\
0 \\
0\end{array}$ & $\begin{array}{l}- \\
31 \\
20\end{array}$ & $\begin{array}{l}- \\
0 \\
0\end{array}$ & $\begin{array}{l}- \\
- \\
-\end{array}$ & $\begin{array}{l}- \\
- \\
-\end{array}$ \\
\hline Wharfe, Boston Spa & SE433457 & $\begin{array}{l}\text { A. brama } \\
\text { L. cephalus } \\
\text { R. rutilus }\end{array}$ & $\begin{array}{l}- \\
19 \\
10\end{array}$ & $\begin{array}{c}- \\
68.42 \\
0\end{array}$ & $\begin{array}{l}- \\
10 \\
11\end{array}$ & $\begin{array}{c}- \\
20 \\
0\end{array}$ & $\begin{array}{l}- \\
10 \\
18\end{array}$ & $\begin{array}{c}- \\
40 \\
0\end{array}$ & $\begin{array}{c}1 \\
29 \\
15\end{array}$ & $\begin{array}{c}100 \\
51.72 \\
0\end{array}$ & $\begin{array}{l}- \\
27 \\
18\end{array}$ & $\begin{array}{c}- \\
44.44 \\
0\end{array}$ & $\begin{array}{c}- \\
2 \\
26\end{array}$ & $\begin{array}{l}- \\
0 \\
0\end{array}$ \\
\hline Aire, Carleton Bridge & SD985502 & $\begin{array}{l}\text { A. brama } \\
\text { L. cephalus } \\
\text { R. rutilus }\end{array}$ & $\begin{array}{l}- \\
5 \\
-\end{array}$ & $\begin{array}{l}- \\
20 \\
-\end{array}$ & $\begin{array}{l}- \\
6 \\
-\end{array}$ & $\begin{array}{l}- \\
0 \\
-\end{array}$ & $\begin{array}{l}- \\
2 \\
-\end{array}$ & $\begin{array}{l}- \\
0 \\
-\end{array}$ & $\begin{array}{c}- \\
24 \\
-\end{array}$ & $\begin{array}{l}- \\
0 \\
-\end{array}$ & $\begin{array}{l}- \\
12 \\
-\end{array}$ & $\begin{array}{l}- \\
0 \\
-\end{array}$ & $\begin{array}{l}- \\
1 \\
-\end{array}$ & $\begin{array}{l}- \\
0 \\
-\end{array}$ \\
\hline Tees, Croft & NZ290098 & $\begin{array}{l}\text { A. brama } \\
\text { L. cephalus } \\
\text { R. rutilus }\end{array}$ & $\begin{array}{l}- \\
- \\
-\end{array}$ & $\begin{array}{l}- \\
- \\
-\end{array}$ & $\begin{array}{l}- \\
19 \\
-\end{array}$ & $\begin{array}{l}- \\
0 \\
-\end{array}$ & $\begin{array}{l}- \\
- \\
-\end{array}$ & $\begin{array}{l}- \\
- \\
-\end{array}$ & $\begin{array}{l}- \\
20 \\
-\end{array}$ & $\begin{array}{l}- \\
0 \\
-\end{array}$ & $\begin{array}{l}- \\
30 \\
-\end{array}$ & $\begin{array}{l}- \\
0 \\
-\end{array}$ & $\begin{array}{l}- \\
28 \\
-\end{array}$ & $\begin{array}{c}- \\
3.57 \\
-\end{array}$ \\
\hline Hull, Hempholme & TA079498 & $\begin{array}{l}\text { A. brama } \\
\text { L. cephalus } \\
\text { R. rutilus }\end{array}$ & $\begin{array}{l}- \\
- \\
-\end{array}$ & $\begin{array}{l}- \\
- \\
-\end{array}$ & $\begin{array}{l}- \\
- \\
24\end{array}$ & $\begin{array}{c}- \\
- \\
12.5\end{array}$ & $\begin{array}{c}- \\
- \\
18\end{array}$ & $\begin{array}{c}- \\
- \\
61.11\end{array}$ & $\begin{array}{c}- \\
- \\
15\end{array}$ & $\begin{array}{c}- \\
- \\
26.67\end{array}$ & $\begin{array}{c}5 \\
- \\
30\end{array}$ & $\begin{array}{c}80 \\
- \\
23.33\end{array}$ & $\begin{array}{l}- \\
- \\
-\end{array}$ & $\begin{array}{l}- \\
- \\
-\end{array}$ \\
\hline Nidd, Kirk Hammerton & SE461546 & $\begin{array}{l}\text { A. brama } \\
\text { L. cephalus } \\
\text { R. rutilus }\end{array}$ & $\begin{array}{l}- \\
- \\
5\end{array}$ & $\begin{array}{l}- \\
- \\
0\end{array}$ & $\begin{array}{c}- \\
4 \\
23\end{array}$ & $\begin{array}{l}- \\
0 \\
0\end{array}$ & $\begin{array}{c}9 \\
10 \\
-\end{array}$ & $\begin{array}{l}0 \\
0 \\
-\end{array}$ & $\begin{array}{l}- \\
- \\
27\end{array}$ & $\begin{array}{l}- \\
- \\
0\end{array}$ & $\begin{array}{c}- \\
30 \\
7\end{array}$ & $\begin{array}{l}- \\
0 \\
0\end{array}$ & $\begin{array}{c}- \\
27 \\
3\end{array}$ & $\begin{array}{c}- \\
18.52 \\
0\end{array}$ \\
\hline Ouse, $\mathrm{u} / \mathrm{s}$ Linton Weir & SE491606 & $\begin{array}{l}\text { A. brama } \\
\text { L. cephalus } \\
\text { R. rutilus }\end{array}$ & $\begin{array}{l}- \\
- \\
-\end{array}$ & $\begin{array}{l}- \\
- \\
-\end{array}$ & $\begin{array}{l}- \\
- \\
-\end{array}$ & $\begin{array}{l}- \\
- \\
-\end{array}$ & $\begin{array}{l}- \\
- \\
-\end{array}$ & $\begin{array}{l}- \\
- \\
-\end{array}$ & $\begin{array}{l}- \\
- \\
-\end{array}$ & $\begin{array}{l}- \\
- \\
-\end{array}$ & $\begin{array}{l}- \\
- \\
-\end{array}$ & $\begin{array}{l}- \\
- \\
-\end{array}$ & $\begin{array}{c}- \\
30 \\
30\end{array}$ & $\begin{array}{c}- \\
3.33 \\
0\end{array}$ \\
\hline $\begin{array}{l}\text { Swale, } \\
\text { Thornton Bridge }\end{array}$ & SE432713 & $\begin{array}{l}\text { A. brama } \\
\text { L. cephalus } \\
\text { R. rutilus }\end{array}$ & $\begin{array}{l}- \\
10 \\
10\end{array}$ & $\begin{array}{l}- \\
0 \\
0\end{array}$ & $\begin{array}{l}- \\
22 \\
18\end{array}$ & $\begin{array}{l}- \\
0 \\
0\end{array}$ & $\begin{array}{l}- \\
20 \\
10\end{array}$ & $\begin{array}{l}- \\
0 \\
0\end{array}$ & $\begin{array}{l}- \\
22 \\
24\end{array}$ & $\begin{array}{c}- \\
4.55 \\
0\end{array}$ & $\begin{array}{c} \\
5 \\
37\end{array}$ & $\begin{array}{l}- \\
0 \\
0\end{array}$ & $\begin{array}{l}- \\
4 \\
8\end{array}$ & $\begin{array}{l}- \\
0 \\
0\end{array}$ \\
\hline
\end{tabular}


appear to lead to poor swimming performance ultimately compromising host survival.

The pathology associated with the parasite is, especially during the early stages, reminiscent of fish exposed to pesticides as described by Couch et al. (1979) and Middaugh et al. (1990). Couch et al. (1979) suggested a number of mechanisms by which herbicides may directly or indirectly influence vertebral dysplasia in fish including influencing or stimulating osteogenic tissues and cells or the hormonal control of calcium utilisation and compartmentalisation in the fish host. It is interesting to speculate on whether M. buckei has a similar mechanism in fish. The determination of the exact mechanisms by which the fish responds to the parasite or the parasite influences the fish's response may assist in development of control methods for myxozoans such as $M$. buckei and $M$. cerebralis that lead to cartilage destruction.

There is strong circumstantial evidence from the current study that $M$. buckei may have a detrimental effect on host populations. Based on histological assessment, the prevalence can be as high as $68 \%$ in certain rivers. In the rivers Ure and Swale, no adults with external symptoms of the disease have been recorded and in the river Wharfe, the number of "stumpy" adults recovered varies between 5\% and 20\% (P. Frear, unpublished observations). As it is unlikely that fish are able to recover from the disease, it can be assumed, based on the severe pathological response, that in some affected populations most of the fry do not survive to recruitment age. The parasite is extremely pathogenic leading ultimately to the death of the host, almost certainly during the first winter. The actual prevalence and distribution of the parasite across the UK and in other areas where the hosts are found are as yet unknown and it would be interesting to address the impact on populations using a multidisciplinary approach involving disease specialists and population biologists. The factors determining host susceptibility and the life cycle of the parasite are currently unknown.

Acknowledgements. The authors wish to acknowledge the technical assistance provided by Mr. Matthew Green, Mr. Eyan Naylor and Miss Kelly Bateman (CEFAS Weymouth), the assistance provided by Environment Agency staff in the collection and identification of fish samples and the riparian owners who provided access to various sites. This work was supported by the Department for Environment, Food and Rural Affairs (contracts F1137, F1138 and C1043).

\section{REFERENCES}

ANDREE K., SZÉKELY C., MOLNÁR K., GRESOVIAC S.J., HEDRICK R.P. 1999: Relationships among members of the genus Myxobolus (Myxozoa: Bivalvulidae) based on small subunit ribosomal DNA sequences. J. Parasitol. 85: 68-74.

BROWN C.L., NÚÑEZ J.M. 1998: Disorders of development. In: J.F. Leatherhead and P.T.K. Woo (Eds.), Fish Disease and Disorders, Volume 2: Non-infectious Disorders. CAB International, Wallingford, pp. 1-18.

BUCKE D., ANDREWS C. 1985: Vertebral anomalies in chub, Leuciscus (Squalius) cephalus L. Bull. Eur. Assoc. Fish Pathol. 5: 3-5.

CHEN C., MA C. 1998: Fauna Sinica. Myxozoa. Myxosporea. Science Press, Beijing, China, 993 pp.

COUCH J.A., WINSTEAD J.T., HANSEN D.J., GOODMAN L.R. 1979: Vertebral dysplasia in young fish exposed to the herbicide trifluralin. J. Fish Dis. 2: 35-42.

ECONOMOU A.N., DAOULAS C., PSARRAS T. 1991: Growth and morphological development of chub, Leuciscus cephalus (L.), during the first year of life. J. Fish Biol. 39: 393-408.

EGUSA S. 1985: Myxobolus buri sp. n. (Myxosporea: Bivalvulida) parasitic in the brain of Seriola quinqueradiata Temminck et Schlegel. Fish Pathol. 19: 239-244.

FEIST S.W., LONGSHAW M. 2000: Myxosporidiosis of fish and the bryozoan link with proliferative kidney disease (PKD) of salmonids. Fish Vet. J. 5: 37-46.

HEDRICK R.P., El-MATBOULI M., ADKISON M.A., MacCONNELL E. 1998: Whirling disease - re-emergence among wild trout. Immunol. Rev. 166: 365-376.
HEDRICK R.P., MacCONNELL E., de KINKELIN P. 1993: Proliferative kidney disease of salmonid fish. Annu. Rev. Fish Dis. 1993: 277-290.

LANDSBERG J.H., LOM J. 1991: Taxonomy of the genera of the Myxobolus/Myxosoma group (Myxobolidae: Myxosporea), current listing of species and revision of synonyms. Syst. Parasitol. 18: 165-186.

LANGDON J.S. 1987: Spinal curvature and an encephalotropic myxosporean, Triangula percae sp. nov. (Myxozoa: Ortholineidae), enzootic in redfin perch, Perca fluviatilis L., in Australia. J. Fish Dis. 10: 425-434.

LANGDON J.S. 1990: Observations on new Myxobolus species and Kudoa species infecting the nervous system of Australian fishes. J. Appl. Ichthyol. 6: 107-116.

LOM J., ARTHUR J.R. 1989: A guideline for the preparation of species descriptions in Myxosporea. J. Fish Dis. 12: $151-156$.

LOM J., DYKOVÁ I. 1992: Protozoan Parasites of Fishes. Developments in Aquaculture and Fisheries Science, Volume 26. Elsevier, Amsterdam, 315 pp.

LOM J., PIKE A.W., DYKOVÁ I. 1991: Myxobolus sandrae Reuss, 1906, the agent of vertebral column deformities of perch Perca fluviatilis in northeast Scotland. Dis. Aquat. Org. 12: 49-53.

MacCONNELL E., VINCENT R.V. 2002: The effects of Myxobolus cerebralis on the salmonid host. In: J.L. Bartholomew and J.C. Wilson (Eds.), Whirling Disease: Reviews and Current Topics. American Fisheries Society, Symposium 29, Bethesda, Maryland, pp. 95-107. 
MAENO Y., SORIMACHI M., OGAWA K., EGUSA S. 1990: [Myxobolus spinacurvatura sp. n. (Myxosporea: Bivalvulida) parasitic in deformed mullet, Mugil cephalus]. Fish Pathol. 25: 37-41. (In Japanese.)

MARKIW M.E. 1992: Experimentally induced whirling disease I. Dose response of fry and adults of rainbow trout exposed to the triactinomyxon stage of Myxobolus cerebralis. J. Aquat. Anim. Health 4: 40-43.

MIDDAUGH D.P., FOURNIE J.W., HEMMER M.J. 1990: Vertebral abnormalities in juvenile inland silversides Menidia beryllina exposed to terbufos during embryogenesis. Dis. Aquat. Org. 9: 109-116.

MOLES A., HEIFETZ J. 1998: Effects of the brain parasite Myxobolus arcticus on sockeye salmon. J. Fish Biol. 52: 146-151.

Received 23 June 2003
MOLNÁR K., ESZTERBAUER E., SZÉKELY C., DÁN Á., HARRACH B. 2002: Morphological and molecular biological studies of intramuscular Myxobolus spp. of cyprinid fish. J. Fish Dis. 25: 643-652.

ROBERTS R.J. 1989: Fish Pathology, 2nd edition. Ballière Tindall, London, $467 \mathrm{pp}$.

ROSE J.D., MARRS G.S., LEWIS C., SCHISLER G. 2000: Whirling behaviour and its relation to pathology of brain stem and spinal cord in rainbow trout. J. Aquat. Anim. Health 12: 107-118.

ROTHWELL J.T., LANGDON J.S. 1990: Spinal curvature associated with Myxobolus sp. cysts in the brain of sandflathead (Platycephalus bassensis L.). J. Appl. Ichthyol. 6: 244-246.

Accepted 25 September 2003 